More information is available via the World Wide Web at $\mathrm{H} 3$ Online: http://www.h3.org/h3. Or, for a printed brochure, send your US mail address to: harvardcup@h3.org. Live coverage of the Harvard Cup will be provided by the Internet Chess Club: http://www.hydra.com/icc.

The Sixth Harvard Cup is sponsored by Mindscape, Inc., the Millburn Corporation, the U.S. Chess Federation, the Internet Chess Club, Cybersmith, and the Computer Museum. The Harvard Cup is produced by $\mathrm{H} 3$ in conjunction with the Harvard Chess Club and the Harvard Computer Society. The Harvard Cup is being held this year in conjunction with the Pan-American Intercollegiate and Scholastic Team Chess Championships, 26-29 December 1995 at the same site (http://www.redweb.companam).

We look forward to seeing you in New York this December for another exciting Harvard Cup.

\title{
CALENDAR OF COMPUTER-GAMES EVENTS 1995/1996
}

\section{December 26-29, 1995}

The Sixth Harvard Cup Human versus Computer Chess Challenge to be held in New York, USA. For details see this issue p. 249.

February 10-17, 1996

A six-game match between World Champion Kasparov and DEEP BLUE to be held in Philadelphia, Penn., USA. For details see ICCA Journal Vol. 18, No. 2, p. 130 and this issue p. 248.

\section{February 16, 1996}

The ACM Computer-Chess Workshop, to be held in Philadelphia, Penn., USA. For details see this issue p. 248.

\section{April 10-12 and 15-17, 1996}

The $11^{\text {th }}$ AEGON Men-Machine Tournament, to be held in The Hague, The Netherlands. Details from Cock de Gorter, Valkenboschkade 607, 2563 JE The Hague, The Netherlands, Telephone: +31 7034643729.

\section{June 27-28, 1996}

The eighth conference of the Advances in Computer Chess, to be held in Maastricht, The Netherlands. For details see this issue p. 251.

\section{ICCA JOURNAL REFEREES IN 1995}

\section{The Editorial Board}

The Editor-in-Chief and The Editorial Board like to acknowledge the expert assistance of the following persons in refereeing submissions to the Journal during 1995 . We hope to meet an equal willingness among the referees for the years to come.
L.V. Allis
D. Kopec
Th. Anantharaman
B. Kuszmaul
H. Bal
T. Mally
D. Beal
T. Marsland
D. McConnell
J. Nievergelt
H. Berliner
M. van der Meulen
J.J. van Oosterwijk Bruyn
M. Campbell
B. Monien
R. Feldmann
P. Mysliwietz
R. Gasser
D. Hartmann
M. Levene
Chr. Posthoff
H. Horacek
R. Levinson
L. de Raedt
B. Hyatt
H. Nelson
A. Reinefeld
J. Schaeffer
R. Seidel
K. Thompson
H. Kaindl
M. Newborn
J.-C. Weill
B. Wendroff 